\title{
OBSERVING SYSTEMS IN THE INDIAN OCEAN
}

Y. Masumoto ${ }^{(1)}$, W. Yu ${ }^{(2)}$, G. Meyers ${ }^{(3)}$, N. D'Adamo ${ }^{(4)}$, L. Beal ${ }^{(5)}$, W. P. M. de Ruijter ${ }^{(6)}$, M. Dyoulgerov ${ }^{(7)}$, J. Hermes ${ }^{(8)}$, T. Lee ${ }^{(9)}$, J. R. E. Lutjeharms ${ }^{(10)}$, J. P. McCreary, Jr. ${ }^{(11)}$, M. J. McPhaden ${ }^{(12)}$, V. S. N. Murty ${ }^{(13)}$, D. Obura $^{(14)}$, C. B. Pattiaratchi ${ }^{(15)}$, M. Ravichandran ${ }^{(16)}$, C. Reason $^{(17)}$, F. Syamsudin ${ }^{(18)}$, G. Vecchi $^{(19)}$, J. Vialard ${ }^{(20)}$, L. Yu ${ }^{(21)}$

${ }^{(1)}$ Research Institute for Global Change, Japan Agency for Marine-Earth Science and Technology, 3173-25 Showa-machi, Kanazawa-ku, Yokohama, Kanagawa 236-0001, Japan;

Email: masumoto@jamstec.go.jp

${ }^{(2)}$ First Institute of Oceanography, State Oceanic Administration, 6 Xianxialing Road, Qingdao 266061, P.R. China; Email: wdyu@fio.org.cn

${ }^{(3)}$ Integrated Marine Observing Sytem, University of Tasmania, Private Bag 110, Hobart TAS 7000 Australia; Email: Gary.Meyers@csiro.au

(4) Perth Regional Programme Office of the Intergovernmental Oceanographic Commission (IOC), UNESCO (United Nations Educational, Scientific and Cultural Organization), PO Box 1370, West Perth, Australia 6872;

Email: N.D'Adamo@bom.gov.au

${ }^{(5)}$ Rosenstiel School of Marine and Atmospheric Science, University of Miami, 4600 Rickenbacker Causeway, Miami, FL 33149, USA; Email: lbeal@rsmas.miami.edu

(6) Institute for Marine and Atmospheric research, Utrecht University, Department of Physics and Astronomy, Princetonplein 5, 3584 CC Utrecht, The Netherlands; Email: w.p.m.deruijter@uu.nl

${ }^{(7)}$ The World Bank, 1818 H Street, NW, Washington DC 20433, USA; Email: mdyoulgerov@worldbank.org

${ }^{(8)}$ SAEON (South African Environmental Observation Network),, Marine and Coastal Management, Private Bag X2, Roggebaai, Cape Town, South Africa, 8012; Email: juliet@saeon.ac.za

${ }^{(9)}$ Jet Propulsion Laboratory, California Institute of Technology, 4800 Oak Grove Dr., Pasadena, CA 91109, USA; Email: tlee@jpl.nasa.gov

${ }^{(10)}$ Department of Oceanography, University of Cape Town, 7700 Rondebosch, South Africa; Email: Johann.Lutjeharms@uct.ac.za

(11) IPRC/SOEST (International Pacific Research Center/School of Ocean and Earth Science and Technology), University of Hawaii, POST Bldg. 413A, 1680 East West Road, Honolulu, Hawaii 96822, USA; Email: jay@hawaii.edu

${ }^{(12)}$ NOAA (National Oceanic and Atmospheric Administration)/Pacific Marine Environmental Laboratory, 7600 Sand Point Way NE 98115 Seattle USA; Email: michael.j.mcphaden@noaa.gov

${ }^{(13)}$ National Institute of Oceanography Regional Centre (Council of Scientific \& Industrial Research), 176 Lawsons Bay Colony, Visakhapatnam 530 017, INDIA; Email: vsnmurty@nio.org

${ }^{(14)}$ CORDIO (Coastal Oceans Research and Development in the Indian Ocean), East Africa, P.O. BOX 10135 Mombasa 80101, Kenya; Email: dobura@cordioea.org

${ }^{(15)}$ School of Environmental Systems Engineering (M015), The University of Western Australia, 35 Stirling Hwy, Crawley,WA6009, Australia; Email: chari.pattiaratchi@uwa.edu.au

${ }^{(16)}$ INCOIS (Indian National Centre for Ocean Information Services), P.B. No. 21, Ocean Valley, Gajularamaram, IDA Jeedimetla, Hyderabad 500 055, India; Email: ravi@incois.gov.in

${ }^{(17)}$ Department of Oceanography, University of Cape Town, Private Bag X3, Rondebosch, Cape Town, South Africa 7701; Email: Chris.Reason@uct.ac.za

${ }^{(18)}$ Badan Pengkajian Dan Penerapan Teknologi, Jl. MH. Thamrin No.8. Jakarta 10340; Email: fadli@webmail.bppt.go.id

${ }^{(19)}$ GFDL (Geophysical Fluid Dynamics Laboratory), Princeton University Forrestal Campus, 201 Forrestal Road, Princeton, NJ 08540-6649, USA; Email: Gabriel.A.Vecchi@noaa.gov

${ }^{(20)}$ Institut de Recherche pour le Développement/Laboratoire d'Océanographie: Expérimentation et Approches

Numériques (LOCEAN), Université Pierre et Marie Curie, 4, Place Jussieu, 75252 Paris Cedex 05, France; Email:jv@locean-ipsl.upmc.fr

${ }^{(21)}$ Woods Hole Oceanographic Institution, 266 Woods Hole Road, Woods Hole, MA 02543, USA; Email:lyu@whoi.edu

\section{ABSTRACT}

This paper reviews development of a basin-scale observing system and regional/coastal observing systems in the Indian Ocean, most of which are implemented by national or institutional projects/programs under international coordination by the Indian Ocean GOOS 
(Global Ocean Observing System) Regional Alliance and the CLIVAR (Climate Variability and Predictability)/GOOS Indian Ocean Panel. Scientific foci of the observing systems, major components, and societal applications are described, and selected scientific results obtained from the data are highlighted.

\section{A BASIN-SCALE OBSERVING SYSTEM: IndOOS}

The Indian Ocean has been known as the ocean with strong influence on monsoon systems, which generate distinct seasonal variations in the upper-ocean. In addition, previous attempts to measure and simulate the ocean variability in the Indian Ocean reveal that there is a rich spectrum of variability spanning from intraseasonal to interannual, decadal, and much longer time-scale phenomena. Combination and interaction among these phenomena cause significant climate variability over and around the Indian Ocean. Despite such an important role of the Indian Ocean for African-Asian-Australian monsoons, climate variability in regions surrounding the Indian Ocean, and its impact on global climate change through atmospheric and oceanic teleconnections, a long-term, sustained observing system in the Indian Ocean had not been started as of about a decade ago, leaving the Indian Ocean as the least observed ocean among the three major basins. Recognizing this observation-gap, an enthusiastic spirit emerged after the OceanObs99 meeting, resulting in the development of a plan for the Indian Ocean Observing System (IndOOS) under the coordination of the CLIVAR/GOOS (Climate Variability and Predictability/Global Ocean Observing System) Indian Ocean Panel.

Before discussing IndOOS in situ measurements, we emphasize that satellite remote sensing is the backbone of the Indian Ocean observing system, and integration of the diverse measurements (in situ and remote) is achieved by ocean state estimation. Satellite measurements provide horizontal distribution maps of the surface variables, such as temperature, sea surface height, and ocean color, as well as several meteorological parameters for the calculation of the air-sea momentum, heat, and fresh water fluxes. Enhancement of remote sensing to include surface salinity will be particularly important for the Indian Ocean due to barrier layer effects and large contrasts across the basin. The satellite data and in situ observation data are complementary to each other, but our understanding of the Indian Ocean variability strongly relies on the satellite data in some regions where the in situ data are sparse. Temporally and spatially high-resolution features of the satellite data enable studies of phenomena across a very wide range of time scales, from intraseasonal to decadal. For example, recent studies using mainly the satellite data, together with some in situ and/or reanalysis data in the Indian Ocean, demonstrate strong sub-seasonal SST (Sea Surface Temperature) variability in the tropical region [1] and [2], meso-scale eddy activities and their relation to the large-scale variability in the current systems [3] and [4], seasonal variations and interannual climate variability [5], [6], [7] and [8], and decadal variability in the basin-scale phenomena [9] and [10]. Sustained

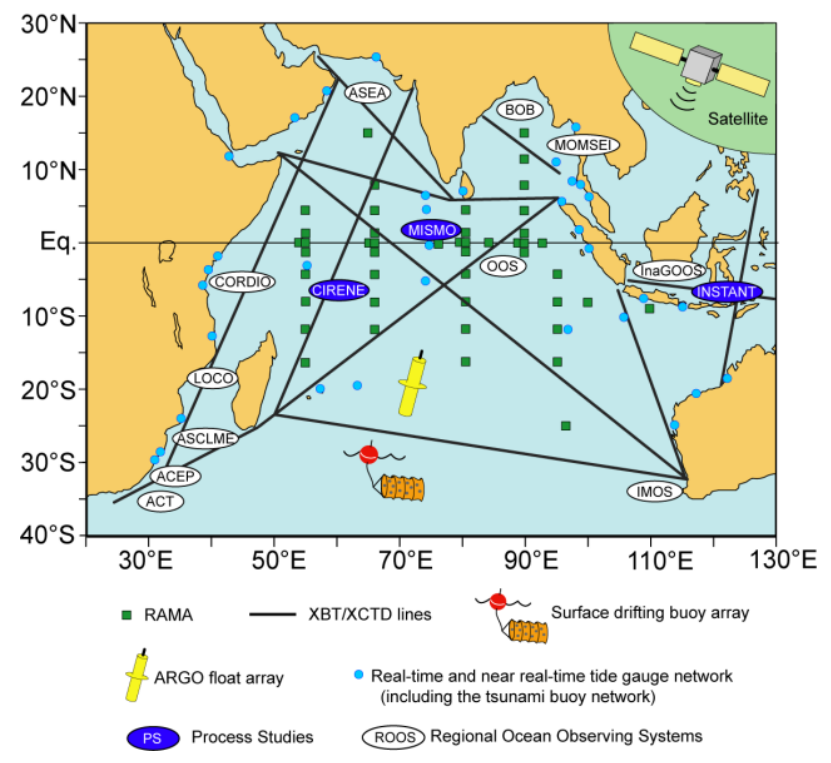

Figure 1: Schematic chart of IndOOS and the ROOS (Regional Ocean Observing Systems). Fixed location in-situ observations of IndOOS are indicated in detail, the Argo and surface drifters scatter widely within the Indian Ocean, and the satellite measurements cover surface observation in the whole area. Regional observing systems and process studies are indicated with white and blue ovals, respectively.

satellite observations of the Indian Ocean are essential for further understanding of the variability in various time-scales, including decadal variations and secular trends.

IndOOS is a multi-platform long-term observing system, which consists of Argo floats, surface drifting buoys, tide gauges, a mooring buoy array, VOS (Voluntary Observing Ship) based XBT/XCTD (Expendable Bathythermograph / Expendable Conductivity-Temperature-Depth probe) sections, and satellite measurements as a backbone observation for sea surface conditions (Fig. 1) [11]. The resources for IndOOS come from diverse national and international bodies. The system is designed to provide high-frequency, near real-time climate-related observations, serving the needs of the intraseasonal, interannual and even decadal time-scale climate studies and climate services in many national meteorological agencies. 


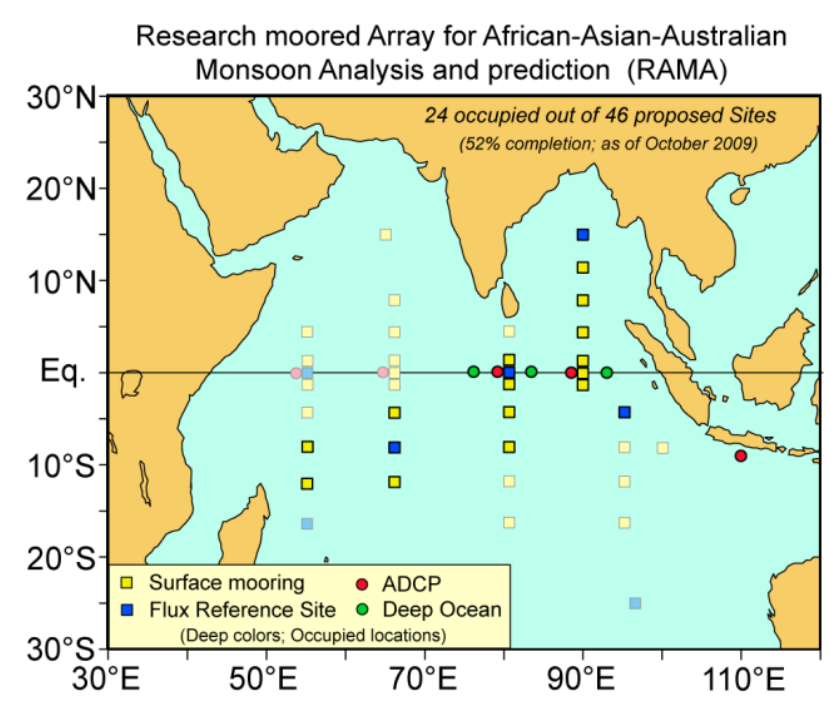

Figure 2: Present status of RAMA implementation as of October 2009. Twenty-two locations out of 46

proposed sites are occupied, basically in the eastern equatorial region, the Bay of Bengal and the southwestern tropical region.

The main platform for in situ observations in the tropical region is the surface and subsurface mooring array, identified as Research moored Array for African-Asian-Australian Monsoon Analysis and prediction (RAMA), which is similar to the TAO/TRITON (Tropical Atmosphere Ocean/ Triangle Trans-Ocean Buoy Network) array in the Pacific and PIRATA (Prediction and Research Moored Array in the Atlantic) [12] and [13]. The proposed RAMA array consists of a total of 46 moorings, of which 38 are ATLAS Autonomous Temperature Line Acquisition System) /TRITON-type surface moorings. Seven of these surface moorings are selected as surface flux reference sites, with enhanced flux measurements (Fig. 2). The surface mooring system can measure temperature and salinity profiles from the surface down to $500 \mathrm{~m}$ depth as well as the surface meteorological variables, and the observed data are transmitted in real-time via Argos satellites. In addition to these surface buoys, there are five subsurface ADCP (Acoustic Doppler Current Profiler) moorings along the equator to observe current profiles in the upper equatorial ocean, and three deep current-meter moorings with ADCPs in the central and eastern equatorial regions. The RAMA array design was evaluated and supported by observing system simulation experiments [14 and 15]. In addition, a subsurface ADCP array along $80^{\circ} \mathrm{E}$ south of Sri Lanka and four deep current-meter moorings with ADCPs near the equator in the eastern basin have been deployed as measurement programs complementary to RAMA.

IndOOS has been implemented rapidly in recent years, largely through bi-national activities involving Japan,
India, USA, Indonesia, China, France, Holland and South Africa. As of October 2009, 24 mooring sites out of 46 planned locations are occupied $(52 \%)$ for RAMA (Fig. 2). By the end of 2010, ten additional moorings are planned for deployment by several countries, which will increase the implementation rate close to $75 \%$ of the full array. However, implementation of RAMA and securing necessary resources to maintain IndOOS are two major issues in the near future. To find the best solution for maximizing the resource use and minimizing the redundancy in the observing system, the IndOOS Resources Forum will be established soon under Indian Ocean GOOS (IOGOOS).

\section{Active Floot Density as on 31 OCT 2009}

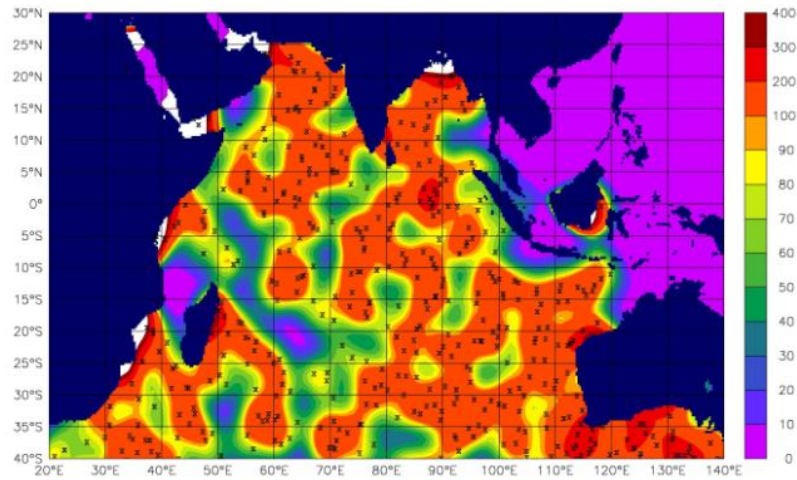

Figure 3: Argo array on 31 October 2009. Yellow to red shading indicates 80 to $>100 \%$ of the

design-sampling density, one float per $3 x 3$ degrees of latitude/longitude.

Early observations of IndOOS provide an invaluable data set for analyses on the Indian Ocean variability. For example, a long-term current observation at $90^{\circ} \mathrm{E}$ on the equator reveals that there is significantly large amplitude intraseasonal variability both in the zonal and meridional components as well as the well-known semi-annual and annual variations [16]. Diagnosis of the zonal momentum balance from long-term current observations further to the west at $80^{\circ} \mathrm{E}$ indicates that the seasonal variations in zonal transport are primarily governed by linear wind-driven ocean dynamics [17]. TRITON buoys deployed in the eastern tropical Indian Ocean successfully capture subsurface evolution of the three consecutive Indian Ocean Dipole events from 2006 to 2008 , with clear negative temperature anomaly at the thermocline depth that appeared a few months before the surface signatures of the IOD events [18], indicating predictability associated with oceanic dynamics. The surface mooring in the Bay of Bengal observed an unusual condition during the passage of cyclone Nargis in May 2008 [19]. The data demonstrate large responses in the upper-ocean and air-sea fluxes, providing a rare opportunity to investigate the responses to such a devastating event. Surface moorings from the RAMA 
array allowed process studies of the SST seasonal cycle [20] and strong upper ocean response to the MJO in the Seychells-Chagos Thermocline Ridge region [21], a region known for strong ocean atmosphere interaction [22]. In addition, the data from the RAMA array has been used by Australian farmers, for example, for making their effective plan of agriculture and pasturing (cf. [12]).

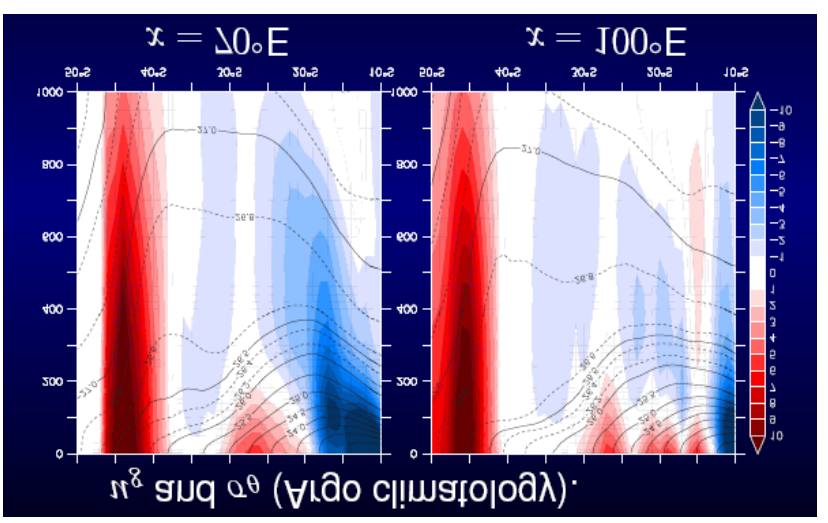

Figure 4. Mean density and zonal geostrophic current observed in the Indian Ocean from Argo data 2004-2009 (Furue and McCreary, personal communication)

Argo floats are another revolutionary change in in-situ ocean observing in the Indian Ocean. The build-up began in 2003 as part of the global description of the variability of the upper ocean thermohaline structure and circulation on seasonal and inter-annual time scales. Data from these floats, together with the satellite based- and other in-situ observations, will enhance the understanding of the ocean circulation pattern and its influence on the global climate variability and will contribute to improve prediction skills of seasonal climate variability. The Indian Ocean (north of $40^{\circ} \mathrm{S}$ ) requires 450 floats to meet the Argo design of one float per $3 \times 3 \mathrm{deg}$. Figure 3 shows the location of the active floats in Indian Ocean as on 31 October 2009, which counts 441 floats deployed by various countries (see also [23]). Note that there are some gaps and other places where more than required floats are present. The Argo program's unprecedented spatial and temporal coverage of density and geostrophic current is opening new perspectives on circulation research. For example, Furue and McCreary (personal communication) have noted that the generation of unusual eastward currents is not well understood and they have postulated a number of mechanisms that can be tested (Fig. 4). The new observations combined with a hierarchy of models are likely to yield on this longstanding, open question. In addition, many new insights on seasonal and interannual variability have come from analysis of the Argo data, including even results on shorter time scales. The results include for example:
- Ocean dynamics in the southeastern warm pool region [24].

- Upper ocean variability of Arabian Sea, such as summer cooling during contrasting monsoons [25], buoyancy flux variations and its role in air sea interaction [26], identifying the observed low-salinity plume off Gulf of Khambhat, India, during post-monsoon period [27], mixed layer variability of western Arabian Sea [28] and seasonal variability of the observed barrier layer [29].

- Variability in upper-ocean freshwater content and its relationship to ENSO (El Niño/Southern Oscillation) and Indian Ocean Dipole modes [30] and [31].

- The importance of upper ocean temperature and salinity during cyclone Nargis [19].

- Upward and westward propagation of subsurface warming in the southern tropical Indian Ocean associated with Rossby waves travelling on the sloping thermocline [32] and [33].

- Intense cooling of the sea surface at intraseasonal time scales in the southern tropical Indian Ocean during austral summer [34] and [35].

- Horizontal distribution of the mixed-layer depth variability associated with the intraseasonal disturbances generated by Madden-Julian Oscillation in the atmosphere ( $\mathrm{Yu}$, personal communication).

- Impact of assimilation of data from Argo floats in simulating temperature and salinity in the Indian Ocean [36], [37], [38], [39], [40] and [41].

A complete list of papers using data from the Argo array may be found on the Argo Project web site http://www.argo.ucsd.edu.

Several SOOP (Ship Of Opportunity Program) XBT lines obtain frequently repeated and high-density section data. The frequently repeated lines in the Indian Ocean are narrow shipping routes allowing nearly exact repeat sections. At least 18 sections per year are recommended in order to avoid aliasing the strong intraseasonal variability in this region. (See also [42]). The CLIVAR/GOOS Indian Ocean Panel (IOP) reviewed XBT sampling in the Indian Ocean and prioritized the lines according to the oceanographic features that they monitor [11]. The highest priority was on lines IX1 and IX8. IX1 monitors the Indonesian throughflow [43]. The IOP recommended weekly sampling on IX1 because of the importance of throughflow in the climate system. IX8 monitors flow into the western boundary region, as well as the Seychelles-Chagos Thermocline Ridge, a region of intense ocean-atmosphere interaction at inter-annual time scales [35] and [22]. IX8 has proven to be logistically difficult so an alternate line may be needed. More than 50 papers have been published based 
wholly or in part on the frequently repeated XBT lines in the Indian Ocean. The research results include:

- Measure the seasonal, interannual and decadal variation of volume transport of major open ocean currents [44], [43], [45], [46] and [47]

- Characterization of seasonal and interannual variation of thermal structure and its relationship to climate and weather e.g. Indian Ocean Dipole, tropical cyclones [48], [49], [50], [51], [52], [53], [54] and [55]

- Surface layer heat budget to identify the relationship between sea surface temperature, depth of the thermocline and ocean circulation at interannual to decadal timescales [56], [57], [58] and [59]

- Rossby and Kelvin wave propagation [60] and [61]

- Validation of variation of thermal structure and currents in models [50] and [62]

As an example of the power of frequently repeated sampling to observe thermal structure and currents, twenty years of data from the three FRX lines in the Indonesian region (IX1, PX2 and IX22) have provided a clear picture of the currents associated with Indonesian throughflow (Fig. 5) [43]. The interannual variability of the currents during this period is well resolved by the FRX sampling and will be the subject of a future study (Wijffels, personal communication).

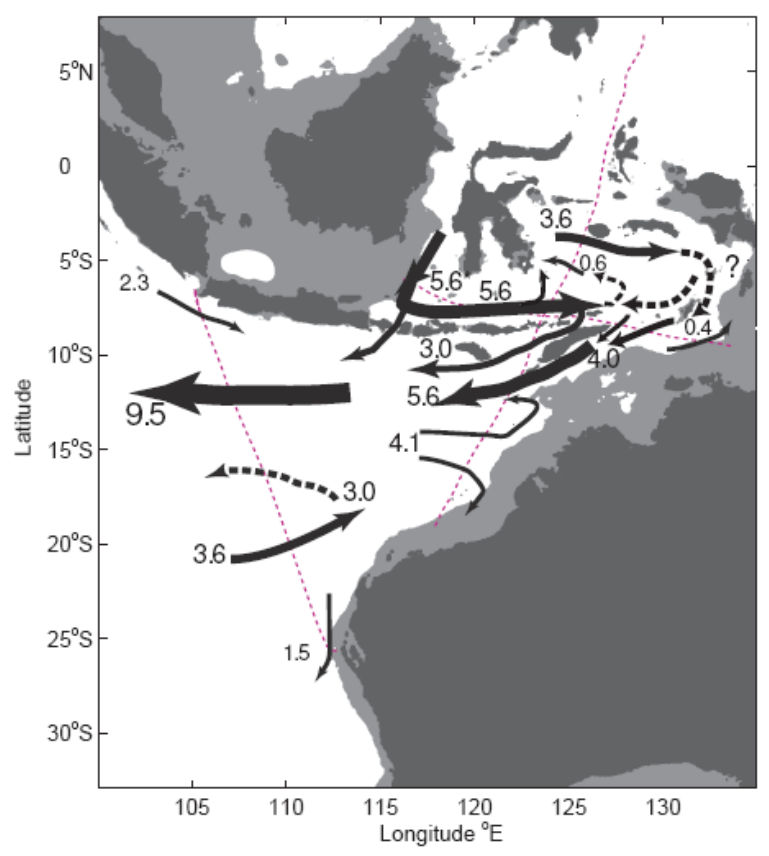

Figure 5. Volume transport of currents in the Indonesian region in Sverdrups, estimated from frequently repeated XBT sections.
The surface drifting buoys are also extensively deployed during a decade after OceanObs'99, and the original surface drifter buoys deployment design, one buoy in every 5-degree box, is almost achieved (e.g. [63]). The key application of surface drifter data is reduction of the bias error in satellite SST measurements. Data are also used for documentation of large-scale surface-current patterns and identifying their role in heat transport and the generation of SST patterns and variability; and potentially for validation of surface currents in ocean models [64]. A problem in the Indian Ocean is that the strong Asian summer monsoon winds drive drifters out of the North Indian Ocean. A more frequent seeding program is needed to maintain the 5-degree sampling. The design sampling density (one drifter per five deg square) is to support calibration of satellite SST. To our knowledge, the sampling density required to map surface currents at say monthly time scale has not been determined, but should be to validate surface currents in models and reanalyses.

The data portal for the Indian Ocean data collected in support of IndOOS is available at http://www.incois.gov.in/Incois/iogoos/home_indoos.jsp, which relies on a distributed network of data archives. The main idea is to provide a one-stop shop for Indian Ocean-related data and data products. The core of the system is a web portal maintained at INCOIS (Indian National Centre for Ocean Information Services), providing direct binary access to the data via OPeNDAP (Open-source Project for a Network Data Access Protocol) and ftp (File Transfer Protocol) protocols. Web-based browsing and data discovery are handled through custom-designed web tools and currently available on servers such as the Live Access Server (LAS). The distributed data archives are maintained by the individual groups at their institutes and made available to the community via the web portal. The portal contains data from basin-scale observations using mooring arrays, Argo profiling floats, expendable bathythermographs (XBT), surface-drifters and tide gauges, as well as the data from regional/coastal observation arrays (ROOS) to observe boundary currents off Africa (WBC (Western Boundary Current)), in the Arabian Sea (ASEA) and Bay of Bengal (BOB), the Indonesian throughflow (ITF), off Australia (EBC (Eastern Boundary Current)) and deep equatorial currents. Satellite derived gridded data sets such as sea surface temperature (TMI ((TRMM (Tropical Rainfall Measuring Mission) Microwave Imager)), sea surface winds (QuikSCAT (Quick Scatterometer Satellite)) and sea surface height anomaly (merged altimeter products) are also available. The agencies contributing to the IndOOS are committed to follow the CLIVAR data policy (http://www.clivar.org/data/data_policy.php). 
For further details of and additional information about the interesting scientific results from IndOOS, an extensive list of papers can be found in IndOOS bibliography site at

http://www.clivar.org/organization/indian/IndOOS/biblio .php.

IndOOS provides the backbone for a number of planned process studies associated with international programs such as Vasco-Cirene [35 and 65], MISMO (Mirai Indian Ocean Cruise for the Study of the MJO-Convection Onset) [66], TRIO (Thermocline Ridge of the Indian Ocean), CINDY2011 (Cooperative Indian Ocean experiment on intraseasonal variability in the Year 2011) [67], DYNAMO (Dynamics of the Madden-Julian Oscillation) [68], and the Year of Tropical Convection [69]. IndOOS also supports the various regional observing systems around the Indian Ocean, which further link IndOOS with the social needs. Incorporation of observations for bio-geochemical parameters will be a necessary future step forward to enhance interdisciplinary research in the Indian Ocean sector. A new satellite that measures surface salinity distribution would be another significant challenge in the Indian Ocean, where the large salinity contrast between the Arabian Sea and the Bay of Bengal plays important role in the climate system of the surrounding regions.

\section{REGIONAL OBSERVING SYSTEMS AROUND THE INDIAN OCEAN}

\subsection{The international and intergovernmental context}

The current suite of Regional Ocean Observing Systems (ROOSs) around the Indian Ocean complement IndOOS - the basin scale OS-by observing the boundary currents, e.g. the Agulhas and Leeuwin Currents. At the same time, they link large-scale ocean structure to continental shelf and coastal regions, where much of the world's population live and work. The various ROOSs are highlighted in Fig. 1 and detailed below. Within the GOOS Regional Alliances (IOGOOS, SEAGOOS (Southeast Asian Global Ocean Observing System), GOOS-Africa and WAGOOS (Western Australian Global Ocean Observing System), regional observing provides a channel for applications of ocean data. The Regional Alliances, IndOOS and regional observing have evolved and matured since OceanObs'99 and are now starting to provide clear benefits to the region's continental margin and island communities that are influenced by the Indian Ocean's oceanographic and coupled climatic processes. But much more can be derived in terms of benefits to these communities under a future scenario of improved integration amongst these various respective observing system initiatives and integrated access to IndOOS and regional data in an interoperable data management framework. Data assimilation products from eddy resolving ocean state estimation (hindcasting and forecasting) are seen as the key integrating factor in the development of applications through the Regional Alliances.

It is now time to consider integrating these observational programs, with a view to facilitating the effective direct application of the knowledge and predictive capacities that are and will continue to be gained from these studies, for example relating to derived ocean-currents and weather systems that transmit to and influence the biodiversity and coastal processes of shelf/nearshore ecosystems. The development and geographical realization of operational forecasting systems that need to be guided by improved hydrodynamic process characterization and facilitated by improved data (for assimilation) provides a compelling case for integration in respect to the complementary suite of ocean observing systems operating in the Indian Ocean. For example, Australia's ocean forecasting system, (BLUElink (Ocean forecasting Australia), (www.bom.gov.au/bluelink) currently provides, at $10 \mathrm{~km}$ horizontal resolution, 3D currents, salinity, temperature and sea surface height anomaly in and around Australia's EEZ (Exclusive Economic Zone). Plans are in place for BLUElink to extend its $10 \mathrm{~km}$ eddy resolving capacity to the Indian Ocean proper and throughout the adjacent South East Asian region. This existing and proposed capacity is highly relevant to the IOC's (Intergovernmental Oceanographic Commission) network of formally and informally recognized GOOS regional Alliances (GRAs) that fall within the geographical influence of the system's current and projected forecasting domain (eg GOOS Africa, IOGOOS, SEAGOOS, WAGOOS). The potential benefits of integrating the ROOS systems and IndOOS in the context of them providing optimal integration and input to ocean-reanalysis and forecasting systems, promises enormous potential benefits to the communities exposed to and affected by oceanic processes, both in the hydrodynamic and coupled climatic senses. Ocean forecasting systems provide direct insights in respect to ocean processes (eg fronts, currents, forces, predictions of long-term manifestations of climate change). They also provide benefits in terms of boundary conditions to force finer scale models, for the examination and prediction of finer scale phenomena at temporal and spatial scales of interest to marine and coastal industry, and local communities and ecologists studying shelf/nearshore ecological issues. As we know, there are often 'treasure troves' of geographically focused data and associated information sets borne out of individual science studies, but the merits and benefits of synergising and harmonising such data/information sets are often not realized due to lack of integration. This paper submits and emphasizes the merit of assigning strong consideration to this objective in the next decade and beyond as a potential major outcome of OceanObs'09. 


\subsection{Integrated Marine Observing System (IMOS) (Australia)}

The Integrated Marine Observing System (IMOS) was established as part of the Australian Government's National Collaborative Research Infrastructure Strategy (NCRIS). Governance and funding of IMOS is discussed in the white paper by Seim et al. [70] IMOS is managed as a national project by the IMOS Office established at the University of Tasmania. Five regional nodes representing agencies and marine researchers have defined the scientific rationale for observing. The overarching scientific goal of IMOS is to understand and model the impacts of major boundary currents (primarily East Australia Current and Leeuwin Current) on the ecosystems of the continental shelf. The research will provide the scientific basis for conservation and management of marine resources under the threat of climate change. The nodes at the present time are Great Barrier Reef, New South Wales, Southern Australia, Western Australia and Bluewater oceans around the continent. Each node has approximately 50 members and has by consensus prepared a Science and Implementation Plan. IMOS has established nine national Facilities to make the observations, which are required by the Nodes. The observing facilities include three for bluewater and climate observations (Argo Australia, Enhanced Measurements from Ships of Opportunity and Southern Ocean Time Series), three facilities for coastal currents and water properties (Moorings, Ocean Gliders and HF (High Frequency) Radar) and three for coastal ecosystems (Acoustic Tagging and Tracking, Autonomous Underwater Vehicle and a biophysical sensor network on the Great Barrier Reef). The operators of the facilities are the major players in marine research in Australia. A satellite remote sensing facility assembles satellite data for the region and the eMarine Information Infrastructure (eMII) provides access to all IMOS data, enhanced data products, and web services in a searchable and interoperable framework. The Science and Implementation Plan for each node and additional information on IMOS are available at http://www.imos.org.au. IMOS supports operational marine and climate information services through BLUElink Ocean Forecasting Australia (http://www.bom.gov.au/bluelink/) and the Predictive Ocean Atmosphere Model for Australia (POAMA http://poama.bom.gov.au/).

\subsection{Indonesian Global Ocean Observing System (InaGOOS)}

The Indonesian monitoring system was established to support applications such as navigation, sea transportation, fishery, marine disaster mitigation, environment monitoring, and marine resource production. The observations also support prediction of marine climate/weather and environmental conditions, protecting marine life, mitigating marine environment changes due to human activities, and for promoting advancement of marine science. The InaGOOS (Indonesian Global Ocean Observing System) science goals are:

- To explore, model and quantify the potential predictability of the marine ecosystem on spatial scales from large basins to the coastal areas

- To support operational oceanography in the Indonesian archipelago

InaGOOS is establishing instrumentation for real time monitoring of physical and biological data to be assimilated in ocean re-analysis and forecast models.

There are seven areas of activity:

- Ocean Hydrodynamics

- Integrated water cycle

- Biochemical fluxes and cycles

- Open ocean and coastal marine pollution

- Sedimentary fluxes and coastal erosion

- Operational fisheries

- Multi-hazard observing systems and early warning

Development of a Marine Data and Information Center is a high priority for the immediate future. The Center will provide data flow and products to user-services.

\subsection{Monsoon Onset Monitoring over Andaman Sea} and its Social \& Ecosystem Impact (MOMSEI)

The Monsoon Onset Monitoring over Andaman Sea and its Social \& Ecosystem Impact (MOMSEI) was launched in early 2009 as a pilot project of Southeast Asian GOOS (SeaGOOS), aiming to build up its regional component in the Andaman Sea. Monsoon brings rainfall for the wider Southeast Asian Basin and its neighboring countries. It could also cause floods/droughts if the monsoon deviates from its normal pattern, thus finally resulting in the disruption of agricultural operation, even displacement of inhabitants. This pilot project, through enhancing the monsoon onset monitoring capability in the Andaman Sea in synergy with the on-going efforts of Indian Ocean Observing System (IndOOS), aims to improve the understanding and forecasting of the monsoon and its multi scale variability. Furthermore, this pilot project will also demonstrate the value of ocean observations for the ecosystem conservation by analyzing the possible link between the anomalous monsoon behaviour and coral reef bleaching in the Andaman Sea.

\subsection{Arabian Sea (ASEA) and Bay of Bengal (BOB) Regional Ocean Observing System (India)}

The Ministry of Earth Sciences, Government of India has established a number of in-situ observation platforms to 
acquire ocean parameters on a real time basis from the seas around India (ASEA (Arabian Sea) and BOB). The basic objective of ASEA and BOB is to understand the dynamics of coastal currents and upper ocean thermohaline structure. The in-situ data and validated satellite data will be assimilated in ocean models for better representation of ocean structure in the North Indian Ocean (past, present and future state of ocean at different temporal and spatial resolutions). The observing system covers coasts, shelves, slopes and the bluewater regions of the whole Bay of Bengal and the eastern Arabian Sea. The measurements include tides, marine meteorological parameters, coastal and nearshore currents, thermal and salinity structure, wave spectrum, sediment characteristics, shoreline changes and beach profiles. Efforts are underway to establish a long term mooring in the northern Bay of Bengal to monitor sub surface temperature, currents and salinity profile including marine meteorological parameters.

The science goals are:

- Understand and model the regional and near shore circulation and processes

- Air-sea interaction studies on diurnal to seasonal scales including intra-seasonal variability

- Validation of satellite data

- BoB Observatory to understand the heat and freshwater budgets, wind and salinity driven circulation, predictability of cyclones, biogeochemistry

The Applications include:

- Support weather/cyclone prediction

- Validate models of regional climate variation and change

- Mitigate coastal erosion and siltation of tidal inlets

- Assess the fate of pollutants

- Manage the health of coastal ecosystems

Societal benefits are tsunami and storm surge warning, nowcasting and forecasting ocean state and nowcasting potential fishing zones.

\subsection{CORDIO-Coral Reef Degradation in the Indian Ocean (Multinational program-Headquarters in Kenya)}

The CORDIO (Coral Reef Degradation in the Indian Ocean) program was launched in the last months of 1998 , as a response to the unprecedented coral mortality throughout the Indian Ocean that year [71]. The aim of the program is to provide information on coral reef degradation and recovery, and socio-economic dependence on reefs in the Indian Ocean region, through a network of researchers and institutions in Kenya, Tanzania, Mozambique, Madagascar, Seychelles, Reunion, Comoros, Mauritius, Maldives, India, Sri Lanka, Thailand and Indonesia. From an initial focus on biophysical monitoring of reefs in support of the GCRMN (Global Coral Reef Monitoring Network) augmented by targeted coral bleaching studies at selected sites, CORDIO developed a broader approach focused on tracking the response of reefs to multiple pressures from local to global levels, and chaired the IUCN (International Union for Conservation of Nature) Global Marine Programme's Climate Change and Coral Reefs working group. In parallel with this, monitoring of socio-economic dependence on reefs was developed, through GCRMN's SocMon (socioeconomic monitoring) Western Indian Ocean programme. In addition, the program supports the study and development of sustainable livelihood activities among local human populations affected by declining coral health, in a bid to improve food and income security of reef-dependent people [72].

Over the decade the CORDIO network has been in operation, it has evolved in response to local and national capabilities and opportunities. Since 2007, the basic monitoring networks have been re-focused into regional research initiatives, such as on reef resilience and connectivity. A new programme combining biological expertise from CORDIO Coastal Oceans Research and Development in the Indian Ocean and oceanographic expertise from the University of Cape Town is looking at how oceanographic processes and connectivity in the northern Mozambique Channel may make this a core region for biodiversity and resilience of the larger WIO (Western Indian Ocean). These initiatives gain from observing systems and networks providing oceanographic and remotely sensed information, and from the increased focus of major funding programmes on coastal areas (e.g. in IOGOOS, ASCLME (Agulhas and Somali Current Large Marine Ecosystems). Further developments in CORDIO will include a similar deepening of socio-economic work to better understand vulnerability to global environmental change and social-ecological interactions. Further, these programmes will be geared towards regional conservation and management planning. Coral reefs are especially vulnerable to threats from local to global levels [73], and can serve as a sentinel system for less obvious but no less important changes in other marine and coastal ecosystems. CORDIO needs to be supported by a sustained, biophysical observing system, access to ocean-reanalysis and forecasting systems and capacity building for network to support greater understanding and management of ocean-wide and global threats to coral reefs. 


\subsection{Long-Term Ocean Climate Observations (LOCO) (Netherlands)}

The LOCO mooring array is located across the narrow section of the Mozambique Channel.

In view of the importance of Agulhas leakage as a connection in the global 'overturning' ocean circulation [74] this program takes sustained synoptic moored observations with the goal to:

- determine in situ variability at interannual (and longer) time scales of the transports in the sources from which the Agulhas Current is fed: the Mozambique Channel (MC) and southern branch of the East Madagascar Current (EMC);

- quantify the magnitude and hydrographic properties of the flow in both areas and use this to estimate the relative importance of (variability in) tropical and subtropical sources on the Agulhas current system and the inter-ocean exchange around South Africa.

Related science results:

- The southward transport through the MC takes place mostly by a regular train of large and deep reaching mesoscale eddies [75] and [76]. Deep countercurrents with intermediate and polar waters flow equatorward along the African continental slope. The eddies travel southward into the Agulhas retroflection region at the southern tip of Africa and affect the interocean exchange [77] and [78].

- Satellite altimeter observations show significant interannual variation of the eddy activity in the Mozambique Channel and east of Madagascar [3]. It appears to be a lagged response to the Indian Ocean Dipole cycle (IOD).

Societal relevance comes from the relation between variability of the flows in the MC and EMC to regional and global climate variability. The latter take place via atmospheric and oceanic teleconnections.

\subsection{Agulhas \& Somali Current Large Marine Ecosystems (ASCLME) (Multinational program -Headquarters in South Africa)}

The Agulhas Current Large Marine Ecosystem (ACLME) stretches from the north end of the Mozambique Channel to Cape Agulhas and is characterised by the swift, warm Agulhas current, a western boundary current that forms part of the anticyclonic Indian Ocean gyre. The Somali Current Large Marine Ecosystem (SCLME) extends from the Comoros Islands and the northern tip of Madagascar up to the Horn of Africa. It is characterised by the monsoon-dominated Somali current, which has a strong, northerly flow during the summer, but reverses its flow in the winter. These two LMEs are both complex and interactive, and are strongly influenced by the South
Equatorial Current. Although the processes and ecosystem functions related to these two LMEs (Large Marine Ecosystems) have a major influence on the societies and economies of the area, very little detailed information is available upon which to base effective, cooperative transboundary management initiatives. ASCLME is a multi-project, multi-agency Programme to institutionalize cooperative and adaptive management of these LMEs. It is in part externally supported by UNEP and the World Bank. The large scale ocean observations are at present primarily a series of research vessel cruises for large-scale baseline-surveys of the biophysical environment. The program includes some moorings in collaboration with RAMA (see [13]) ASCLME recognises the need in the longer term to establish a network of sustained observations to support adaptive management. As with CORDIO the socio-economic goals of ASCLME should be supported by access to ocean-reanalysis and forecasting systems.

\subsection{African Coelacanth Ecosystem Program (ACEP) (South Africa)}

The ACEP is a coastal program associated with ASCLME. It operates moorings and ship surveys on the shelf, some as a sustained monitoring activity. The purpose is to investigate the impacts of large-scale processes on the shelf and coastal waters. Specific goals are:

- Integrate the physical and biological sciences to understand the processes that govern South West Indian Ocean (SWIO) ecosystem functioning;

- Use innovative science to unravel coelacanth evolutionary adaptations and phylogenies of these ecosystems;

- Conduct long-term monitoring of ecosystems to understand biological processes and climate change;

- Determine species richness, biodiversity and biogeography of SWIO;

- Provide recommendations for SWIO conservation, management strategies and long-term sustainability;

- Build capacity in offshore marine sciences, particularly developing a critical mass of skilled personnel and addressing equity imbalances;

- Promote public awareness and understanding of marine science;

- Generate knowledge and build integrated and shared marine (geographic) information systems;

- Promote ACEP as a platform for national, regional and international partnerships (e.g. with SANCOR (South African Network for Coastal and Oceanic Research) and ASCLME) that strengthen South African marine science. 


\subsection{Agulhas Current Time-series (ACT): Towards a multi-decadal index of Agulhas Current transport.}

Monitoring the Agulhas Current is a powerful way to keep one's "finger on the pulse" of intraseasonal to long-term variability across the Indian Ocean and into the Atlantic, where Agulhas leakage impacts the climatically important overturning circulation. ACT is a US-led, NSF-funded project with the goal of building a multi-decadal time series of Agulhas Current volume transport as a contribution to IndOOS and GOOS. The first phase of ACT will begin in March 2010 with the deployment of an array of moored instruments across the Agulhas Current off South Africa, along an altimeter ground track, to obtain a three-year time series of transports via in situ measurements. The second phase will be to correlate the along-track altimeter data with these measured transports to produce a proxy for Agulhas Current transport, which can be extended forwards and backwards in time, providing information about decadal variability. Agulhas variability is an important climate index for the Indian Ocean, which can be compared to other climate indices, such as the Indian Ocean Dipole and the Atlantic Meridional Overturning, as well as to other western boundary currents, such as the Florida Current and Kuroshio time series.

\section{THE WAY FORWARD: FUTURE OBSERVING SYSTEMS IN THE INDIAN OCEAN}

Briefly, the immediate challenges for development in the Indian Ocean are:

- Completion of RAMA is the most urgent priority. IOP has set 2012 as the target date for occurring all of the planned sites. As of October 2009, many mooring locations in the western and southern Indian Ocean remain to be occupied.

- A higher level of coordination across all activities (i.e. across different IndOOS platforms and across regional and basin-scale development) is required. Each observing activity mentioned above has its own background, motivations, perspectives, strategy, funding resources and observation plans. Some are focusing on the biogeochemical/ ecosystem observations, while others are interested in the observation of the physical parameters. In order to minimize redundancy among the projects and to obtain maximum benefits from the observing systems, further coordination of the observation plans is essential.

- Efficient accumulation, synthesis and distribution of the observed data and value-added products are essential for active scientific progress and enhancement of applications to socio-economic benefits in the Indian Ocean rim countries.

- To facilitate active participation from the Indian Ocean rim countries, it is necessary to enhance capacity building activities for transfer of observational and modeling techniques and of the knowledge about data utilization.

We recognize that further integration of the physical and biogeochemical/ecosystem observations, as well as stronger links among the basin-scale, regional, and satellite-based observing systems is required for the development of the indispensable observing systems in the Indian Ocean. Some steps to address these challenges have been initiated.

Under auspices of GODAE and with support from the UNESCO (United Nations Educational, Scientific and Cultural Organization) IOC Perth Regional Programme Office and University of Western Australia, an "International Summer-School of Oceanography" will be held in Perth, Australia in January 2010 to promote the development and use of ocean-reanalysis products. The target participants are oceanography $\mathrm{PhD}$ students, ocean forecaster-trainees, middle ware product developers, government agencies and specialist marine managers.

An initiative by the Indian Ocean GOOS regional alliance with assistance from the UNESCO IOC Perth Regional Programme Office will sponsor a series of workshops to promote use of ocean reanalysis products by agencies and marine managers in developing countries around the Indian Ocean. The first workshop is also likely to be held in Perth early in 2010.

IOGOOS has also recommended establishing the IndOOS Resources Forum (IRF). The IRF members will be high-level ocean and climate research managers. They will biennially review the rationale for implementation of the IndOOS Plan and the extent to which it is meeting its mission goals, as articulated by the IOP and other relevant expert-bodies. Based on its deliberations at face-to-face meetings, the IRF will intersessionally facilitate and coordinate the provision of the resources required for IndOOS implementation. The IRF activity will promote contributions from institutions in the participating countries, with a view toward completing IndOOS by 2012. Pending completion and acceptance of a business plan, the first meeting of the IRF is likely to be in mid-2010.

A biogeochemical science alliance, akin and complementary to the Indian Ocean Panel for GOOS/CLIVAR, but focussing on the biogeochemistry and ecology of the Indian Ocean, is being considered and likely to form as a group endorsed and supported through IOGOOS, IMBER (Integrated Marine Biogeochemistry and Ecosystem Research) and the UNECO IOC Perth Regional Programme Office. This group is to be called SIBER (Sustained Indian Ocean Biogeochemical and Ecological Research) and will operate in close integration and synergy with the Indian Ocean Panel of 
GOOS/CLIVAR. The IRF will have relevance to SIBER's needs.

Appendix: Point of contact for the regional observing systems

\section{Integrated Marine Observing System (Australia)}

Gary Meyers (Gary.Meyers@csiro.au); Tim Moltmann (Tim.Moltmann@csiro.au)

\section{Indonesian Global Ocean Observing System (InaGOOS)}

Fadli Syamsudn (fadli@webmail.bppt.go.id); Aryo Hanggono (arfahan@geologist.com)

3. Monsoon Onset Monitoring over Andaman Sea and its Social\&Ecosystem Impact (MOMSEI)

Weidong Yu (wdyu@fio.org.cn); Somkiat Khokiattiwong (skhokiattiwong@gmail.com)

4. Arabian Sea (ASEA) and Bay of Bengall (BOB) Regional Ocean Observing System (India)

M. Ravichandran (ravi@incois.gov.in); V. Rajendran (raju@niot.res.in)

\section{CORDIO-Coral Reef Degradation in the Indian Ocean (Kenya)}

David Obura (obura@africaonline.co.ke)

\section{Long-Term Ocean Climate Observations (LOCO) (Netherlands)}

Will De Ruijter (w.p.m.deruijter@uu.nl); Herman Ridderinkhof (idd@nioz.nl)

\section{Agulhas \& Somali Current Large Marine Ecosystems Project}

David Vousden (david.vousden@asclme.org); J.R.E. Lutjeharms (jre@mweb.co.za)

8. Agulhas Current Time-series (ACT): Towards a multi-decadal index of Agulhas Current transport.

Lisa Beal (lbeal@rsmas.miami.edu)

\section{African Coelacanth Ecosystem Program (South Africa)}

Mike Roberts (squid@metroweb.co.za); Juliet Hermes (juliet@saeon.ac.za)

\section{REFERENCES}

1. Harrison, D.E. \& Vecchi, G.A. (2001). January 1999 Indian Ocean Cooling Event, Geophys. Res. Lett., 28 (19), 3717-3720.

2. Saji, N.H., Xie, S.-P. \& Tam, C.-Y. (2006). Satellite observations of intense intraseasonal cooling events in the tropical South Indian Ocean. Geophys. Res. Lett., 33, L14704, doi:10.1029/2006GL026525.

3. Palastanga, V., van Leeuwen, P.J. \& de Ruijter, W.P.M. (2006). A link between low-frequency mesoscale eddy variability around Madagascar and the large-scale Indian Ocean variability. J. Geophys. Res., 111, C09029, doi:10.1029/2005JC003081.

4. Feng, M., Majewski, L.J., Fandry, C.B. \& Waite, A.M. (2007). Characteristics of two counter-rotating eddies in the Leeuwin Current system off the Western Australian coast. Deep-Sea Research II, 54, 961-980.

5. Chambers, D.P., Tapley, B.D. \& Stewart, R.H. (1999). Anomalous warming in the Indian Ocean coincident with El Nino, J. Geophys. Res., 104, 3035 - 3047.

6. Saji, N.H., Goswami, B.N., Vinayachandran, P.N. \& Yamagata, T. (1999). A dipole mode in the tropical Indian Ocean., Nature, 401, 360-363.

7. Yu, L. \& Rienecker M.M. (2000). Indian Ocean Warming of 1997-1998, J. Geophys. Res., 105(C7), 16,923-16,939.

8. Yu, L., Jin, X. \& Weller R.A. (2007). Annual, seasonal, and interannual variability of air-sea heat fluxes in the Indian Ocean, J. Clim., 20, 3190 - 3209.

9. Lee, T. (2004). Decadal weakening of the shallow overturning circulation in the South Indian Ocean, Geophys. Res. Lett., 31, L18305, doi:10.1029/2004GL020884.

10. Lee, T. \& McPhaden, M.J. (2008). Decadal phase change in large-scale sea level and winds in the Indo-Pacific region at the end of the 20th century. Geophys. Res. Lett., 35, L01605, doi:10.1029/2007GL032419.

11. International CLIVAR Project Office (2006). Understanding the Role of the Indian Ocean in the Climate System-Implementation Plan for Sustained Observations. ICPO Publication Series 100; GOOS Report No. 152; WCRP Informal Report No. 5/2006, International CLIVAR Project Office, Southhampton UK, 60 pp, 30 fig's.

12. McPhaden M.J. \& Co-authors (2009). RAMA: The Research Moored Array for African-Asian-Australian Monsoon Analysis and Prediction, Bull. Am. Meteorol. Soc., 90, 459-480.

13. McPhaden, M. \& Co-Authors (2010). "The Global Tropical Moored Buoy Array" in these proceedings (Vol. 2), doi:10.5270/OceanObs09.cwp.61. 
14. Oke, P.R. \& Schiller, A. (2007). A Model-Based Assessment and Design of a Tropical Indian Ocean Mooring Array. J. Climate, 20, 3269.

15. Vecchi, G.A. \& Harrison, M.J. (2007). An observing system simulation experiment for the Indian Ocean. $J$. Climate, 20, 3300-3319.

16. Masumoto, Y., Hase, H., Kuroda, Y., Matsuura, H. \& Takeuchi, K. (2005). Intraseasonal variability in the upper layer currents observed in the eastern equatorial Indian Ocean, Geophys. Res. Letter, 32, L02607, doi:10.1029/2004GL021896.

17. Nagura, M. \& McPhaden, M.J. (2008). The dynamics of zonal current variations in the central equatorial Indian Ocean. Geophys. Res. Lett., 35, L23603, doi:10.1029/2008GL035961.

18. Horii, T., Hase, H., Ueki, I. \& Masumoto, Y. (2008). Oceanic precondition and evolution of the 2006 Indian Ocean dipole, Geophys. Res. Lett., 35, L03607, doi:10.1029/2007GL032464.

19. McPhaden, M.J., Foltz, G.R., Lee, T., Murty, V.S.N., Ravichandran, M., Vecchi, G.A., Vialard, J., Wiggert, J.D. \& Yu, L. (2009). Ocean-atmosphere interactions during cyclone Nargis, EOS, 90, 53-54.

20. Foltz, G.R., Vialard, J., Praveen Kumar B. \& McPhaden, M.J. (2009). Seasonal mixed layer heat balance of the southwestern tropical Indian Ocean, J. Clim., in press.

21. Vialard, J., Foltz, G., McPhaden, M.J., Duvel, J-P. \& de Boyer Montégut, C. (2008). Strong Indian Ocean sea surface temperature signals associated with the Madden-Julian Oscillation in late 2007 and early 2008, Geophys. Res. Lett., 35, L19608, doi:10.1029/2008GL035238.

22. Xie, S.-P., Annamalai, H., Schott, F.A. \& McCreary, J.P. (2002). Structure and Mechanisms of South Indian Ocean Climate Variability. J. Climate, 15, 864-878.

23. Freeland, H. \& Co-Authors (2010). "Argo - A Decade of Progress" in these proceedings (Vol. 2), doi:10.5270/OceanObs09.cwp.32.

24. Ravichandran M., Vinayachandran, P.N., Joseph, S. \& Radhakrishnan, K. (2004). Results from the first Argo float deployed by India. Current Science, 86(5), 651-659.

25. Vinayachandran, P.N. (2004). Summer cooling of the Arabian Sea during contrasting monsoons. Gephys. Res. Lett., 31, L13306, doi:10.1029/2004GL019961.

26. Anitha, G., Ravichandran, M. \& Sayanna, R. (2008). Surface buoyancy flux in the Bay of Bengal and Arabian Sea. Annales Geophysicae, 26 (3), 395-400.

27. Rao AD., Joshi, M. \& Ravichandran, M. (2009). Observed low-salinity plume off Gulf of Khambhat, India, during post-monsoon period. Geophys. Res. Lett., 36, L03605.

28. Bhaskar, T.V.S.U., Swain, D. \& Ravichandran, M. (2006). Inferring mixed-layer depth variability from Argo observations in the western Indian Ocean. J. Mar. Res. 64 (3): $393-406$
29. Thadathil, P., Muraleedharan, P.M., Somayajulu, Y.K., Gopalakrishna, V.V., Reddy, G.V., Thoppil, P., Rao, R.R., Murtugudde, R. \& Revichandran, C. (2008). Seasonal Variability of the Observed Barrier Layer in the Arabian Sea. J. Phys. Oceanogr., 38, 624-638.

30. Phillips, H.E., Wijffels, S.E. \& Feng, M. (2005). Interannual variability in the freshwater content of the Indonesian-Australian Basin. Geophys. Res. Lett. 32, L03603.

31. Rao, S.A., Gopalkrishnan, V.V., Shetye, S.R. \& Yamagata, T. (2002). Why were cool SST anomalies absent in the Bay of Bengal during the 1997 Indian Ocean dipole event? Geophys. Res. Lett., 29, 1555, doi:10.1029/2001GL014645.

32. Chowdary J.S., Gnanaseelan, C., Xie, S.P. (2009) Westward propagation of barrier layer formation in the 2006-07 Rossby wave event over the tropical southwest Indian Ocean. Geophys. Res. Lett., 36, L04607.

33. Yu, W., Xiang, B., Liu, L. \& Liu, N. (2005). Understanding the origins of interannual thermocline variations in the tropical Indian Ocean, Geophys. Res. Lett., 32, L24706, doi:10.1029/2005GL024327.

34. Vinayachandran, P.N. \& Saji, N.H. (2008). Mechanisms of South Indian Ocean intraseasonal cooling. Geophys. Res. Lett., 35, L23607, doi:10.1029/2008GL035733.

35. Vialard, J., Duvel, J-P., McPhaden, M., Bouruet-Aubertot, P., Ward, B., Key, E., Bourras, D., Weller, R., Minnett, P., Weill, A., Cassou, C., Eymard, L., Fristedt, T., Basdevant, C., Dandoneau, Y., Duteil, O., Izumo, T., de Boyer Montégut, C., Masson, S., Marsac, F., Menkes, C. $\&$ Kennan, S. (2009). Cirene: Air Sea Interactions in the Seychelles-Chagos thermocline ridge region, Bull. Am. Met. Soc., 90, 45-61.

36. Oke, P.R. \& Schiller, A. (2007). Impact of Argo, SST and altimeter data on an eddy-resolving ocean reanalysis. Geophys. Res. Lett., 34 (19), L19601.

37. Agarwal, N., Sharma, R., Basu, S. et al., (2008) Assimilation of sub-surface temperature profiles from Argo floats in the Indian Ocean in an Ocean General Circulation Model. Current Science, 95 (4), 495-501.

38. Schiller, A., Oke, P.R., Brassington, G., Entel, M., Fiedler, R., Griffin, D.A. \& Mansbridge, J.V. (2008). Eddyresolving ocean circulation in the Asian-Astralian region inferred from an ocean reanalysis effort. Progress in Oceanography, 76 (3), 334-365.39. Oke, P.R., Brassington, G.B., Griffin, D.A. \& Schiller, A. (2008). The Bluelink ocean data assimilation system (BODAS). Ocean Modelling, 21 (1-2), 46-70.

40. Krishnamurti, T.N., Chakraborty, A., Krishnamurti, R., Dewar, W.K. \& Clayson, C.A. (2007). Passage of intraseasonal waves in the subsurface oceans. Geophys. Res. Lett., 34 (14), L14712.

41. Huang, B.Y., Xue, Y. \& Behringer, D.W. (2008). Impacts of Argo salinity in NCEP Global Ocean Data Assimilation System: The tropical Indian Ocean. $J$. Geophys. Res., 113, C08002, doi:10.1029/2007JC004388. 
42. Goni, G. \& Co-Authors (2010). "The Ship of Opportunity Program" in these proceedings (Vol. 2), doi:10.5270/OceanObs09.cwp.35.

43. Wijffels, S.E., Meyers, G. \& Godfrey, J.S. (2008). A Twenty Year Average of the Indonesian Throughflow: Regional Currents and the Inter-basin Exchange. J. Phys. Oceanogr 38 (8), 1-14.

44. Wainwright, L., Meyers, G., Wijffels, S. \& Pigot, L. (2008). Change in the Indonesian Throughflow with the climatic shift of 1976/77. Geophys. Res. Lett., 35, L03604, doi:10.1029/2007GL031911.

45. Potemra, J. (2005). Indonesian Throughflow transport variability estimated from Satellite Altimetry. Oceanography, 18, 99-107.

46. Sprintall J., Wijffels, S., Chereskin, T. \& Bray, N. (2002). The JADE and WOCE I10/IR6 Throughflow sections in the southeast Indian Ocean. Part 2: velocity and transports. Deep Sea Research Part II: Topical Studies in Oceanography, 49, 1363-1389.

47. Murty, V.S.N., Sarma, M.S.S., Lambata, B.P., Gopalakrishna, V.V., Pednekar, S.M., Rao, S.A., Luis, A.J., Kaka, A.R. \& Rao, L.V.G. (2000). Seasonal variability of upper-layer geostrophic transport in the tropical Indian Ocean during 1992-1996 along TOGA-I XBT tracklines, Deep-sea Research Part I, 47, 1569 1582.

48. Jodhav, S.K. \& Munot, A.A. (2008). Warming SST of Bay of Bengal and decrease in formation of cyclonic disturbances over the Indian region during southwest monsoon season, Theor. Appl. Climatol., doi:10.1007/S00704-008-0043-3.

49. Sakova, I., Meyers, G. \& Coleman, R. (2006). Interannual variability in the Indian Ocean using altimeter and IX1-expendable bathy-thermograph (XBT) data: Does the 18-month signal exist? Geophysical Research Letters, 33 (20) $1-5$.

50. Cai, W., Hendon, H. \& Meyers, G. (2005). Indian Ocean dipole-like variability in the CSIRO Mark 3 coupled climate model. J. Climate, 18, 1449-1468.

51. Qu, T. \& Meyers, G. (2004). Seasonal characteristics of circulation in the southeastern tropical Indian Ocean. $J$. Phys Oceanogr., 35, 255-267.

52. Feng, M. \& Meyers, G. (2003). Interannual variability in the tropical Indian Ocean: a two-year time-scale of Indian Ocean Dipole. Deep Sea Research Part II: Topical Studies in Oceanography, 50, 2263-2284.

53. Rao, S.A., Behera, S.K., Masumoto, Y. \& Yamagata, T. (2002). Interannual variability in the subsurface tropical Indian Ocean with a special emphasis on the Indian Ocean Dipole, Deep-Sea Res. II, 49, 1549-1572.

54. Gopalakrishna, V.V., Ali, M.M., Araligidad, N., Shenoi, S., Shum C.K. \& Yi, Y. (2003). An atlas of XBT thermal structures and TOPEX/POSEIDON sea surface heights in the North Indian Ocean. NIO-NRSA-SP-01-03, NIO Special Publication.
55. Meyers, G. (1996). Variation of Indonesian throughflow and the El Niño - Southern Oscillation. J. Geophys. Res., 101, 12,255-12,263.

56. Alory, G. \& Meyers, G. (2009). Warming of the Upper Equatorial Indian Ocean and Changes in the Heat Budget (1960-1999). J. Climate, 22 (1), 93-113.

57. Du, Y., Qu, T. \& Meyers, G. (2008). Interannual variability of the sea surface temperature off Java and Sumatra in a global GCM. J. Climate, 21, 2451-2465.

58. Alory, G., Wijffels, S. \& Meyers, G. (2007). Observed temperature trends in the Indian Ocean over 1960-1999 and associated mechanisms. Geophys. Res. Lett. 34, L02606, doi:10.1029/2006GL028044.

59. Qu, T., Du, Y., Strachan, J., Meyers, G. \& Slingo, J. (2005). Sea surface temperature and its variability in the Indonesian Seas. Oceanography, 18, 50-61.

60. Wijffels, S. \& Meyers, G. (2004). An intersection of oceanic waveguides - variability in the Indonesian throughflow region. J. Phys. Oceanogr., 34, 1232-1253

61. Masumoto, Y. \& Meyers, G. (1998). Forced Rossby Waves in the Southern Tropical Indian Ocean. J. Geophys. Res., 103, 27,589-27,602.

62. Schiller, A. (2004). Effects of explicit tidal forcing in an OGCM on the water-mass structure and circulation in the Indonesian throughflow region. Ocean Modelling, 6, 31-49.

63. Lumpkin, R. \& Goni, G. (2008). State of the ocean in 2007: surface currents. In "State of the Climate in 2007", Bulletin of the American Meteorological Society, 89.

64. Lumpkin, R. \& Pazos, M. (2007). Measuring surface currents with SVP drifters: the instrument, its data, and some recent results. Chapter 2 of Lagrangian Analysis and Prediction of Coastal and Ocean Dynamics, Ed. A. Griffa, A. D. Kirwan, A. J. Mariano, T. Ozgokmen and T. Rossby, Cambridge University Press.

65. Duvel, J-P., Basdevant, C., Bellenger, H., Reverdin, G., Vargas, A. \& Vialard, J. (2009). The Aeroclipper: A New Device to Explore Convective Systems and Cyclones, Bull. Am. Met. Soc., 90, 63-71.

66. Yoneyama, K., Masumoto, Y., Kuroda, Y., Katsumata, M., Mizuno, K., Takayabu, Y.N., Yoshizaki, M., Shareef, A., Fujiyoshi, Y., McPhaden, M.J., Murty, V.S.N., Shirooka, R., Yasunaga, K., Yamada, H., Sato, N., Ushiyama, T., Moteki, Q., Seiki, A., Fujita, M., Ando, K., Hase, H., Ueki, I., Horii, T., Yokoyama, C. \& Miyakawa T. (2008). MISMO Field Experiment in the Equatorial Indian Ocean. Bull. Amer. Meteor. Soc., 89, 1889-1903.

67. CINDY2011 Science Plan, accessed on 31 October 2009 at www.jamstec.go.jp/iorgc/cindy/docs/CINDY2011_Plan Ver1-2.pdf (password-protected) from http://www.jamstec.go.jp/iorgc/cindy/plans.html.

68. DYNAMO White paper, accessed on 31 October 2009 at www.eol.ucar.edu/projects/dynamo/

69. YOTC Science Plan, accessed on 31 October 2009 at www.ucar.edu/yotc/documents/YOTC Science Plan.pdf 
70. Seim, H., Dahlin, H., Meyers, G., Shuford, R. and Proctor, R., (2010). "Development of Delivery of Services from Ocean Observing Systems - An Opportunity to Promote Common Approaches for a Global Ocean Observing System" in these proceedings (Vol. 2), doi:10.5270/OceanObs09.cwp.77.

71. Wilkinson, C., Linden, O., Cesar, H., Hodgson, G., Rubens, J. \& Strong, A. (1999). Ecological and socioeconomic impacts of 1998 coral mortality in the Indian Ocean: An ENSO impact and a warning of future change? Ambio 28, 188-196.

72. Obura, D.O., Tamelander, J., \& Linden, O. (Eds) (2008). Ten years after bleaching - facing the consequences of climate change in the Indian Ocean. CORDIO Status Report 2007. CORDIO (Coastal Oceans Research and Development, Indian Ocean)/Sida-SAREC. Mombasa. http//:www.cordioea.org/ ISBN 91-973959-5-1. 500 pp.

73. Veron, J.E.N., Hoegh-Guldberg, O., Lenton, T.M., Lough, J.M., Obura, D.O., Pearce-Kelly, P., Sheppard, C.R.C., Spalding, M., Stafford-Smith, M.G. \& Rogers, A.D. (2009). The coral reef crisis: The critical importance of $<350 \mathrm{ppm} \mathrm{CO}_{2}$. Marine Pollution Bulletin, 58, 1428-1436. doi:10.1016/j.marpolbul.2009.09.009

74. De Ruijter, W.P.M., Biastoch, A., Drijfhout, S.S., Lutjeharms, J.R.E., Matano, R.P., Pichevin, T., Van Leeuwen, P.J. \& Weijer, W. (1999). Indian-Atlantic inter-ocean exchange: dynamics, estimation and impact J. Geophys. Res., 104, 20885-20910.

75. De Ruijter, W.P.M., Ridderinkhof, H., Lutjeharms, J.R.E., Schouten, M.W. \& Veth, C.W. (2002). Observations of the flow in the Mozambique Channel. Geophysical Research Letters, doi:10.1029/2001GL013714.

76. Ridderinkhof, H. \& De Ruijter, W.P.M. (2003). Moored current observations in the Mozambique Channel, Deep-Sea Res. II, 50, 1933-1957.

77. Schouten, M.W., De Ruijter W.P.M. \& Van Leeuwen, P.J. (2002). Upstream control of Agulhas Ring shedding, J.Geophys. Res., doi:10.1029/2001JC000804.

78. Schouten, M.W., De Ruijter, W.P.M., Van Leeuwen, P.J. \& Dijkstra, H.A. (2002). An oceanic teleconnection between the equatorial and southern Indian Ocean, Geophys.Res.Lett. doi:10.1029/2001GL014542. 